\title{
Chronic opioid use: a risk factor for central sleep apnoea and successful therapy with adaptive pressure support servo-ventilation
}

\author{
${ }^{1} \mathrm{~A}$ Fahim, ${ }^{2} \mathrm{AO}$ Johnson \\ ${ }^{1}$ Consultant Respiratory Physician, New Cross Hospital, Wolverhampton; ${ }^{2}$ Consultant Respiratory Physician, Department of Respiratory \\ Medicine, Pinderfields Hospital, Wakefield, West Yorkshire, UK
}

\begin{abstract}
Sleep apnoea is a global health problem with significant morbidity. Obesity is a well-known risk factor for this condition, however chronic intake of opioids as a risk factor for central sleep apnoea is under-recognised. We report a case of a 47-year-old man who developed significant sleep-disordered breathing secondary to opioid use for chronic pain. A sleep study demonstrated a picture of complex sleep apnoea with a prominent central sleep apnoea component. He had no significant improvement with conventional continuous positive airway pressure therapy. However, adaptive servo-ventilation had a dramatic effect on his symptoms and compliance. This case highlights the significant risk of central sleep apnoea with opioid use and illustrates the importance of adaptive servo-ventilation in the management of sleep-disordered breathing secondary to impaired central respiratory drive.
\end{abstract}

Correspondence to A Fahim Department of Respiratory Medicine, New Cross Hospital, Wolverhampton Road, Wolverhampton WVIO OQP, UK

\section{tel. +44 (0)190 230799}

e-mail ahmedfahim@doctors.org.uk

KEYWORDS Opioids, adaptive servo-ventilation, central sleep apnoea

DECLARATION OF INTERESTS No conflicts of interest declared.

\section{INTRODUCTION}

Sleep apnoea is a relatively common condition with a prevalence of $4 \%$ in the general population.' It is classified into obstructive and central sleep apnoea (CSA). Central sleep apnoea can be subdivided into primary or idiopathic and secondary forms. Secondary CSA is associated with medical conditions such as heart failure, stroke, acromegaly $y^{2,3}$ and renal failure. ${ }^{4}$ Acute and chronic ingestion of opioids has also been linked with the development of CSA. ${ }^{5-8}$

\section{CASE HISTORY}

A 47-year-old male with a background of sleep apnoea, hypertension and chronic back pain presented to our sleep clinic with complaints of loud snoring, un-refreshed sleep, daytime sleepiness, frequent headaches and a poor sleep pattern. His Epworth score was II out of 24. He had never smoked and did not drink alcohol. The patient's weight was $108 \mathrm{~kg}$ with a body mass index (BMI) of 33 . He was medicated with morphine sulphate (I $20 \mathrm{mg}$ daily), dosulepin, paracetamol and propranolol. He was started on a lower dose of morphine initially. However, unsatisfactory pain control led to increase of morphine dose to $120 \mathrm{mg}$. He was on this dose at the time of referral to our centre. An ear, nose and throat examination showed a long palate but good oral hygiene. The rest of the systemic examination was unremarkable. He underwent a trial of continuous positive airway pressure (CPAP) therapy (with fixed pressures) without significant symptomatic improvement despite good compliance. This was followed by a trial of non-invasive ventilation through bilevel positive airway pressure (BPAP) for a few months which was not tolerated well. Both airway pressure trials were carried out at another centre and failure to respond to both modalities prompted the referral to our centre.

\section{INVESTIGATIONS AND MANAGEMENT}

Overnight oximetry showed a remarkably high $4 \%$ desaturation index of 57. A respiratory sleep study with chest and abdominal sensors confirmed the oximetry findings of severe sleep apnoea with an apnoea hypopnoea index (AHI) of 62. Most apnoeas (97\%) were central without obstructive episodes (Table I). As our patient had already undergone trials of CPAP and BPAP at a previous sleep centre, he was commenced on adaptive servo-ventilation (ASV) with an immediate dramatic improvement in his symptoms. A follow-up sleep study (Table I) confirmed objective improvement in his ventilation with a normalised $\mathrm{AHI}$ and a mean oxygen saturation $\left(\mathrm{SpO}_{2}\right)$ improvement to $95 \%$.

His compliance with the device was excellent with nine hours use every night and his daytime sleepiness and headaches resolved completely. A repeat Epworth score was recorded as $3 / 24$ and he is currently well 12 months after the initial presentation. 
TABLE I Sleep study and polysomnography data.Adaptive servo-ventilation had a dramatic improvement in the number of central apnoeas and symptoms with reduction in Epworth score from 13 to 3 .

\begin{tabular}{|l|c|c|c|}
\hline Measure & $\begin{array}{l}\text { Respiratory } \\
\text { sleep study } \\
\text { Nasal flowl } \\
\text { chest and } \\
\text { abdominal } \\
\text { sensors and } \\
\text { oximetry }\end{array}$ & $\begin{array}{l}\text { Polysomno- } \\
\text { graphy }\end{array}$ & $\begin{array}{l}\text { Adaptive } \\
\text { servo- } \\
\text { ventilation } \\
\text { (ASV) }\end{array}$ \\
\hline $\begin{array}{l}\text { Apnoea } \\
\text { Index }\end{array}$ & 54 & 33.5 & 1.2 \\
\hline $\begin{array}{l}\text { Apnoea } \\
\text { Hypopnoea } \\
\text { Index }\end{array}$ & 62 & 33.5 & 1.2 \\
\hline $\begin{array}{l}\text { Total } \\
\text { number of } \\
\text { apnoeas }\end{array}$ & 419 & 225 & 10 \\
\hline \multicolumn{1}{|c|}{ Central } & $408(97 \%)$ & $200(89 \%)$ & $9(90 \%)$ \\
\hline Obstructive & 0 & 0 & I (I0\%) \\
\hline \multicolumn{1}{|c|}{ Mixed } & $\mathrm{II}(3 \%)$ & $25(\mathrm{I} \%)$ & 0 \\
\hline $\begin{array}{l}\text { Total } \\
\text { number of } \\
\text { hypopnoeas }\end{array}$ & 63 & 0 & 0 \\
\hline $\begin{array}{l}\text { Mean } \\
\text { oxygen } \\
\text { saturation } \\
\text { (SpO })\end{array}$ & $94 \%$ & $\mathrm{~N} / \mathrm{A}$ & $95 \%$ \\
\hline 4\% dip rate & 58 & $\mathrm{~N} / \mathrm{A}$ & 0 \\
\hline $\begin{array}{l}\text { Epworth } \\
\text { score }\end{array}$ & $\mathrm{II}$ & $\mathrm{I} 3$ & 3 \\
\hline N/A: Not applicable & & \\
\hline & & & \\
\hline & & & \\
\hline
\end{tabular}

\section{DISCUSSION}

This case illustrates a significant global issue faced by sleep physicians since the liberalisation of opioid use following a joint statement on treatment of chronic pain by the American Academy of Pain Medicine and the American Pain Society in 1997.' It was suggested that respiratory depression induced by opioids is a shortlived phenomenon and is experienced predominantly by opioid-naïve patients. Since then, a number of studies s,8,10-12 $^{72}$ have demonstrated that $30-90 \%$ of patients on chronic opioid therapy have evidence of sleep apnoea with a pattern of severity in a dose-dependent manner. ${ }^{7}$ Opioid use is associated not only with CSA but also with ataxic breathing. Ataxic or irregular breathing is distinct from Cheyne-Stokes respiration (a breathing pattern with very regular cyclical change in tidal volume occurring with very obvious periodicity). There is no pattern or regularity in ataxic breathing. In other words, it is synonymous with 'atrial fibrillation' but in terms of respiration. In a retrospective cohort study of 60 patients with chronic opioid intake, ataxic breathing was found in $92 \%$ of subjects on a morphine dose equivalent to $200 \mathrm{mg}$ or higher. $^{7}$ Each $100 \mathrm{mg}$ morphine doseequivalent was associated with a $29 \%$ increase in the rate of central apnoeas. Another interesting observation in the study was an inverse relationship between BMI and severity of AHI.

The pathophysiologic mechanisms of opioid-related sleep-disordered breathing are poorly understood. Individuals on long-term opioids develop tolerance to their central effects. ${ }^{13}$ However, failure of adaptation to peripheral effects via chemoreceptors may account for the development of CSA. In this regard, $\mu$-opioid receptor inhibition of carotid bodies may play a significant role in respiratory depression in association with narcotics use on a long-term basis. It is evident from a number of studies that chronic narcotics ingestion is associated with a form of complex sleep apnoea, having components of both CSA and upper airway obstruction. ${ }^{10,11,14}$ The pattern of sleep-disordered breathing observed in patients on chronic opioids is distinct from the breathing pattern in systolic heart failure. In patients with cardiac failure, the breathing is characterised by a gradual decrescendo arm ending in a central apnoea which is followed by a long crescendo arm. ${ }^{15}$ In contrast, the disordered breathing pattern observed with chronic opioid use is similar to ataxic breathing, with abrupt breaths at the end of apnoea. Despite these differences in the breathing patterns in both disorders, ASV is effective in treating sleepdisordered breathing associated with systolic heart failure as well as chronic narcotics use. ${ }^{16,17}$

While the management of obstructive sleep apnoea is generally successful with CPAP therapy, the strategy to manage mixed apnoeas, central apnoeas and complex sleep apnoea is more complicated and there is no universally agreed consensus on treatment guidelines. Other options to consider in these patients are noninvasive positive pressure ventilation (NIPPV) or ASV. Adaptive servo-ventilation is a relatively new approach to treating CSA and Cheyne-Stokes respiration, using a small but varying amount of pressure support ventilation. It uses a pre-set (or auto-titrating) expiratory pressure to deal with any obstructive apnoeas or hypopnoeas, but also generates variable inspiratory pressure support above the expiratory pressure that deals (on a breath by breath basis) with the fluctuating inspiratory efforts that result in the central apnoeas and hypopnoeas. This strategy ensures the hydrostatic benefits of low-level nasal CPAP without the risk of over-ventilation. Morgenthaler et al. compared the efficacy of ASV and NIPPV in a crossover trial in patients with centrally mediated breathing abnormalities and found ASV to be more effective in controlling sleep-disordered breathing and respiratory arousal index than NIPPV. ${ }^{18}$ Both of these modalities were superior to CPAP. These findings suggest that ASV is a better mode of ventilatory support for patients with complex sleep apnoea. 


\section{CONCLUSION}

This case highlights the potential harmful effect of chronic opioid intake (at a modest dose) on sleeprelated breathing. Moreover, it demonstrates the value of ASV in the management of complex sleep apnoea with a prominent CSA component.The exact pathophysiological mechanisms of narcotics-induced sleep disruption and ASV need to be elucidated in greater detail in long-term prospective studies to improve management of this clinical issue.

\section{REFERENCES}

I Bixler EO, Vgontzas AN, Lin HM et al. Prevalence of sleepdisordered breathing in women: effects of gender. Am J Respir Crit Care Med 200I; 163:608-13.

2 Grunstein RR, Ho KY, Sullivan CE. Sleep apnea in acromegaly. Ann Intern Med 1991; I 15:527-32.

3 Grunstein RR, Ho KY, Berthon-Jones M et al. Central sleep apnea is associated with increased ventilatory response to carbon dioxide and hypersecretion of growth hormone in patients with acromegaly. Am J Respir Crit Care Med 1994; I50:496-502.

4 Venmans BJ, van Kralingen KW, Chandi DD et al. Sleep complaints and sleep disordered breathing in hemodialysis patients. Neth J Med 1999; 54:207-12. http://dx.doi.org/I0. I0 I6/S0300-2977(99)000 I8-2

5 Mogri M, Khan MI, Grant BJ et al. Central sleep apnea induced by acute ingestion of opioids. Chest 2008; I33:| 484-8. http://dx.doi. org/I0.1378/chest.07-I89|

6 Farney RJ, Walker JM, Boyle KM et al. Adaptive servoventilation (ASV) in patients with sleep disordered breathing associated with chronic opioid medications for non-malignant pain.J Clin Sleep Med 2008; 4:3II-9.

7 Walker JM, Farney RJ, Rhondeau SM et al. Chronic opioid use is a risk factor for the development of central sleep apnea and ataxic breathing. J Clin Sleep Med 2007; 3:455-6I.

8 Farney RJ,Walker JM, Cloward TV et al. Sleep-disordered breathing associated with long-term opioid therapy. Chest 2003; 123:632-9. http://dx.doi.org//0.1378/chest.123.2.632

9 The use of opioids for the treatment of chronic pain. A consensus statement from the American Academy of Pain Medicine and the American Pain Society. Clin J Pain 1997; 13:6-8.
I0 Teichtahl H, Prodromidis A, Miller B et al. Sleep-disordered breathing in stable methadone programme patients: a pilot study. Addiction 200I; 96:395-403. http://dx.doi.org/I0.1046/j. I360-0443.200I.9633954.x

I I Wang D, Teichtahl H, Drummer O et al. Central sleep apnea in stable methadone maintenance treatment patients. Chest 2005; 128:1348-56. http://dx.doi.org/10.1378/chest.128.3.1348

I2 Alattar MA, Scharf SM. Opioid-associated central sleep apnea: a case series. Sleep Breath 2009; 13:201-6. http://dx.doi.org/I0.1007/ s I |325-008-022 |-7

I3 SantiagoTV, Goldblatt K,Winters K et al. Respiratory consequences of methadone: the response to added resistance to breathing. Am Rev Respir Dis 1980; 122:623-8.

I4 Javaheri S, Malik A, Smith J et al. Adaptive pressure support servoventilation: a novel treatment for sleep apnea associated with use of opioids. J Clin Sleep Med 2008; 4:305-10.

I5 Javaheri S. Central sleep apnea. In: Lee-Chiong TL, editor. Sleep: a comprehensive handbook. New Jersey: John Wiley \& Sons, Inc; 2006. pp. 249-62.

16 Szollosi I, O'Driscoll DM, Dayer MJ et al. Adaptive servo-ventilation and deadspace: effects on central sleep apnoea. J Sleep Res 2006; I 5: I 99-205. http://dx.doi.org/ I0. I I I I/j. I365-2869.2006.005 I5.x

17 Pepperell JC, Maskell NA, Jones DR et al.A randomized controlled trial of adaptive ventilation for Cheyne-Stokes breathing in heart failure. Am J Respir Crit Care Med 2003; 168: I 109-14. http://dx.doi. org/10.1I64/rccm.2002/2-14760C

18 Morgenthaler TI, Gay PC, Gordon N et al.Adaptive servoventilation versus noninvasive positive pressure ventilation for central, mixed, and complex sleep apnea syndromes. Sleep 2007; 30:468-75.

\section{SENIOR FELLOWS' CLUB PRIZE}

A prize of $£ 250$ will be awarded to the first-named (or corresponding) author of an original research paper on a clinical topic, deemed by a panel of judges to be the best paper by a doctor-in-training (i.e. pre-consultant level) published in the The Journal of the Royal College of Physicians of Edinburgh in 2012. The best paper will be selected by a panel of judges, including a senior Fellow, an active clinician and a member of the editorial team.

Further details may be obtained from the Editorial Office, RCPE, 9 Queen Street, Edinburgh, EH2 IJQ, tel 0I3। 2473652 or email editorial@rcpe.ac.uk. 